\title{
A case of group A streptococcal meningitis in an adult
}

\author{
ANDREW LS PATTULLO, MD, ERIC J BOW, MD
}

\begin{abstract}
ALS Pattullo, EJ Bow. A case of group A streptococcal meningitis in an adult. Can $J$ Infect Dis 1993;4(4):223-226. Group A streptococci are an important cause of soft tissue infections but have rarely been reported as the cause of pyogenic meningitis since the advent of antibiotics. A case of group A streptococcal meningitis in an adult is presented along with a review of similar cases reported in the literature. This case serves to illustrate the virulent nature of this pathogen in infections of the meninges, the potential for associated complications, and the need for rapid diagnosis and appropriate treatment. The source of infection in this and many other cases in the literature is the upper respiratory tract. The case presented responded well to antibiotics but resulted in permanent auditory-vestibular dysfunction.
\end{abstract}

Key Words: Adult, Group A streptococci, Meningitis

\section{Méningite à streptocoque du groupe $\mathrm{A}$ chez un adulte}

RÉSUMÉ: Les streptocoques du groupe A sont une cause importante d'infection des tissus mous, mais ont rarement été observés dans l'étiologie de la méningite pyogène depuis l'avènement des antibiotiques. Un cas de méningite à streptocoque du groupe $\mathrm{A}$ chez l'adulte est présenté ici avec une synthèse des cas similaires déclarés dans la littérature. Ce cas sert à illustrer la nature virulente de ce pathogène dans les infections des méninges, les complications potentielles qui y sont associées et la nécessité d'un diagnostic prompt et d'un traitement approprié. Dans ce cas et dans plusieurs autres cas publiés, la source de l'infection se situe dans les voies respiratoires supérieures. Le cas présenté a bien répondu aux antibiotiques, mais a eu pour séquelle une dysfonction auditive vestibulaire permanente. 
$\mathrm{G}$ ROUP A BETA-HEMOLYTIC STREPTOCOCCI ARE A COMMON cause of soft tissue infection and pharyngitis in adults (1) but are infrequently implicated in meningitis. Prior experience has revealed this group of organisms to be particularly virulent in this setting. This report details a case of meningitis due to group A betahemolytic streptococci in an adult that illustrates some of the characteristics of this infection.

\section{CASE PRESENTATION}

A sixty-six-year-old man was admitted to hospital with a two-day history of fever, left ear pain and increasing confusion. He had symptoms of an upper respiratory tract infection including coryza and sore throat for one week before admission. His left ear began to drain yellowish fluid on the day of admission, he became disoriented with inappropriate speech and began vomiting. His past medical history included deafness of the right ear for several years, and a remote myocardial infarction.

Physical examination revealed a temperature of $39.2^{\circ} \mathrm{C}$ orally, respirations of $28 / \mathrm{min}$, pulse of 76 beats/min and blood pressure of $130 / 72 \mathrm{mmHg}$. The patient was somnolent with inappropriate speech and was unable to understand spoken commands, possibly because of deafness. Nuchal rigidity was present, however Kernig's and Brudzinsky's signs were absent. The oropharynx was unremarkable. There was a purulent discharge from the left ear where the tympanic membrane was perforated. A fourth heart sound and a grade two of six ejection systolic murmur were heard over the precordium.

White blood cell (WBC) count was $19.8 \times 10^{9} / \mathrm{L}$ with $90.5 \%$ segmented neutrophils. Hemoglobin was $137 \mathrm{~g} / \mathrm{L}$. Gram stain of sputum showed a moderate amount of pus cells and a large number of mixed bacteria. Gram stain of the discharge from the left ear showed a small amount of pus cells and large numbers of Grampositive cocci. A cerebrospinal fluid (CSF) sample revealed a WBC of $2780 \times 10^{6} / \mathrm{L}$ with $79 \%$ segmented neutrophils and a red blood cell count of $400 \times 10^{6} / \mathrm{L}$. CSF glucose was $3.7 \mathrm{mmol} / \mathrm{L}$ (serum glucose 7.1 $\mathrm{mmol} / \mathrm{L}$ ) and protein was $1.71 \mathrm{~g} / \mathrm{L}$. Bacterial antigen detection in the CSF was negative for Streptococcus pneumoniae, Neisseria meningitidis and Haemophilus influenzae type $\mathrm{b}$.

Radiographs of the paranasal sinuses and chest were unremarkable. Computed tomography of the head showed no cerebral abnormality or bony defect, however fine cuts through the left middle and external ear revealed fluid filling several of the mastoid air cells consistent with mastoiditis (Figure 1).

Therapy was begun with penicillin G $3 \times 10^{6}$ units intravenously every $4 \mathrm{~h}$ and cefotaxime $2 \mathrm{~g}$ intravenously every $6 \mathrm{~h}$. The patient became afebrile after one day of therapy. Blood and urine cultures from admission remained negative, but swabs from the nose, throat and left ear grew group A beta-hemolytic strep-

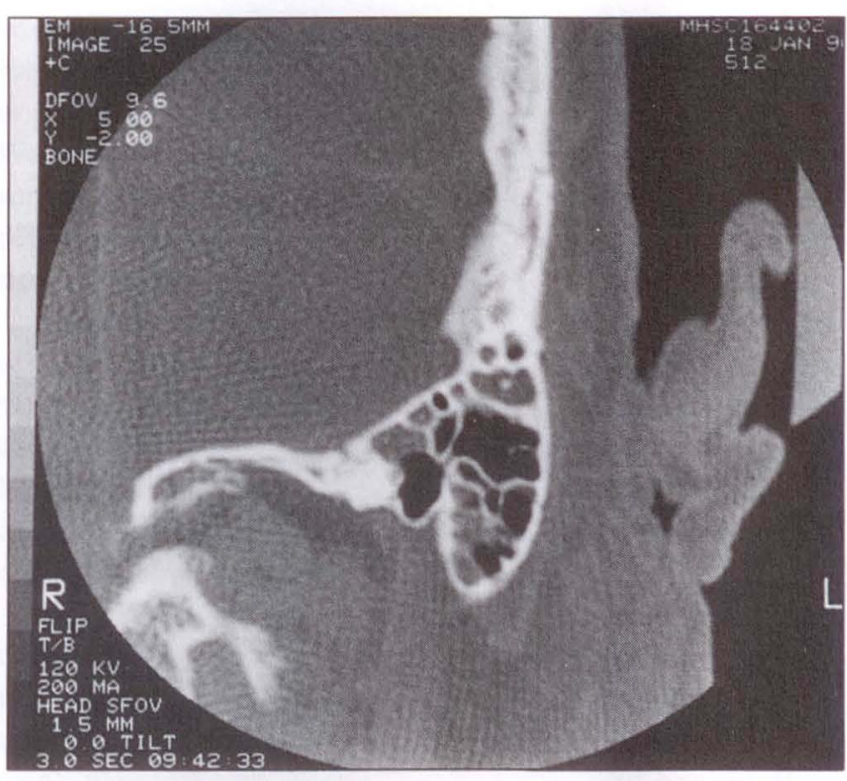

Figure 1) Computed axial tomography scan through the left mastoid showing flud in several of the air cells, consistent with mastoiditis

tococcus after one day. The same organism was grown from the CSF after two days incubation. Cefotaxime was discontinued after one day of therapy, and penicillin was continued for 10 days intravenously followed by four days orally.

The patient made a rapid recovery but had persistent left-beating nystagmus, vertigo and deafness at the end of therapy. A short course of intravenous steroids begun midway through antibiotic therapy did not improve hearing loss, which persisted six months later. Audiometry revealed a profound, bilateral, sensorineural hearing loss at greater than $90 \mathrm{~dB}$ throughout the range 200 to $8000 \mathrm{~Hz}$. There was also a persistent perforation of the left tympanic membrane.

\section{DISCUSSION}

Group A streptococci have long been important human pathogens, being the most common cause of bacterial pharyngitis and cellulitis. They are also the trigger for the secondary nonpyogenic sequelae of rheumatic fever and post-streptococcal glomerulonephritis. Recently, serious infections and sequelae caused by these organisms have increased $(2,3)$. Particularly of note are reports of a toxic shock-like syndrome caused by exotoxin-producing group A streptococci (4). In spite of the frequency of serious infections with group A streptococci, they have been a rare cause of bacterial meningitis during the antibiotic era, being isolated in less than $0.2 \%$ of cases (5). When group A streptococcal meningitis does occur, however, the consequences can be serious.

A search of the literature found 11 other cases of group A streptococcal meningitis in adults (6-14). Chow and Muder (14) discuss eight of these cases in a review 
TABLE 1

Characteristics of cases of group A streptococcal meningitis

\begin{tabular}{|c|c|c|c|c|c|c|c|}
\hline $\begin{array}{l}\text { Age } \\
\text { (years) }\end{array}$ & Sex & $\begin{array}{l}\text { Associated } \\
\text { conditions }\end{array}$ & $\begin{array}{l}\text { Symptoms and } \\
\text { duration (days) }\end{array}$ & $\begin{array}{l}\text { Source of positive } \\
\text { cultures }\end{array}$ & Treatment & Outcome & $\begin{array}{l}\text { Reference } \\
\text { (year) }\end{array}$ \\
\hline 31 & $F$ & & $\begin{array}{l}\text { 'Cold' (7), vomiting, } \\
\text { confusion (1) }\end{array}$ & Blood, CSF & $\begin{array}{l}\text { Penicillin, } \\
\text { cloxacillin }\end{array}$ & Death & $6(1971)$ \\
\hline 24 & M & $\begin{array}{l}\text { Skull fracture through } \\
\text { frontal sinus two } \\
\text { days prior }\end{array}$ & & CSF & Ampicillin & Recovery & $7(1973)$ \\
\hline 80 & $\mathrm{~F}$ & $\begin{array}{l}\text { Septic arthritis, } \\
\text { cancer of rectum } \\
\text { and breast }\end{array}$ & $\begin{array}{l}\text { Arthritis (12), fever, } \\
\text { confusion (1) }\end{array}$ & $\begin{array}{l}\text { Joint fluid, } \\
\text { blood, CSF }\end{array}$ & $\begin{array}{l}\text { Cefotaxime (prior), } \\
\text { penicillin } G\end{array}$ & Recovery & $8(1982)$ \\
\hline 23 & $\mathrm{~F}$ & & $\begin{array}{l}\text { Diarrhea, sore throat, } \\
\text { vaginitis }\end{array}$ & $\begin{array}{l}\text { CSF, blood, } \\
\text { throat, vagina, } \\
\text { cervix, urethra }\end{array}$ & Ceftriaxone & $\begin{array}{l}\text { Recovery, } \\
\text { optic } \\
\text { neuritis }\end{array}$ & $12(1984)$ \\
\hline 63 & $\mathrm{~F}$ & $\begin{array}{l}\text { Primary biliary } \\
\text { cirrhosis }\end{array}$ & $\begin{array}{l}\text { Headache, sore } \\
\text { throat (5) }\end{array}$ & $\begin{array}{l}\text { Oropharynx, } \\
\text { blood, CSF }\end{array}$ & Penicillin G & Recovery & $9(1985)$ \\
\hline 29 & $\mathrm{~F}$ & $\begin{array}{l}37 \text { weeks pregnant, } \\
\text { maxillary sinusitis }\end{array}$ & Coryza (7) & $\begin{array}{l}\text { Maxillary sinus } \\
\text { fluid }\end{array}$ & $\begin{array}{l}\text { Ampicillin, } \\
\text { gentamicin }\end{array}$ & $\begin{array}{l}\text { Recovery, } \\
\text { normal } \\
\text { delivery }\end{array}$ & $10(1986)$ \\
\hline 63 & & Postmyelography & & CSF & $\begin{array}{l}\text { Penicillin, } \\
\text { chloramphenicol }\end{array}$ & Recovery & $13(1988)$ \\
\hline 68 & M & $\begin{array}{l}\text { Chronic scalp ulcer } \\
\text { extending to bone }\end{array}$ & Headache (2) & CSF & $\begin{array}{l}\text { Penicillin } G \\
\text { ceftriaxone }\end{array}$ & Death & 11 (1989) \\
\hline 51 & M & $\begin{array}{l}\text { Cranial surgery for } \\
\text { epidural sinus four } \\
\text { days prior }\end{array}$ & $\begin{array}{l}\text { Headache, } \\
\text { fever (1) }\end{array}$ & CSF & Penicillin G & Recovery & 11 (1989) \\
\hline 81 & M & Bullous pemphigoid & $\begin{array}{l}\text { Lethargy, altered } \\
\text { mentation ( } 1 \text { ) }\end{array}$ & CSF & Penicillin & Recovery & $14(1992)$ \\
\hline 65 & $\mathrm{~F}$ & Otitis media & URTI, ear pain (5) & CSF & $\begin{array}{l}\text { Ampicillin, } \\
\text { ceftriaxone }\end{array}$ & $\begin{array}{l}\text { Recovery, } \\
\text { mild } \\
\text { hearing } \\
\text { loss left ear }\end{array}$ & 14 (1992) \\
\hline 66 & M & $\begin{array}{l}\text { Otitis media, } \\
\text { mastoiditis }\end{array}$ & $\begin{array}{l}\text { Coryza (7), ear pain } \\
(2), \text { confusion ( } 1 \text { ) }\end{array}$ & $\begin{array}{l}\text { Pharynx, nose, } \\
\text { ear, CSF }\end{array}$ & $\begin{array}{l}\text { Penicillin G, } \\
\text { cefotaxime }\end{array}$ & $\begin{array}{l}\text { Recovery, } \\
\text { deafness }\end{array}$ & $\begin{array}{l}\text { Present } \\
\text { case } \\
\text { (1993) }\end{array}$ \\
\hline
\end{tabular}

CSF Cerebrospinal fluid; URTI Upper respiratory tract infection

of the subject. The present review adds the case presented and three others reported in the literature. The findings of these and the case being discussed are summarized in Table 1. The patients range in age from 23 to 81 years, mean 53.7 years, with an even mix of males and females. In all but one (92\%) there was another underlying condition and/or focus of infection preceding meningitis. This suggests that group A streptococci rarely infect the meninges primarily before forming a focus of infection elsewhere. Symptoms specific to the central nervous system were absent in all cases until one to two days before presentation with meningitis. Altered mentation was noted in four cases $(33 \%)$ at presentation.

The meningitis in the present patient was likely initiated by colonization of the mucosa of the nasopharynx (as documented by positive throat and nasal cultures), followed by contiguous spread through the eustachian tube to the middle ear and mastoid air cells resulting in otitis media and mastoiditis. Organisms may then have spread via the internal acoustic meatus or the diploic veins to the meninges. The lack of positive blood cultures weighs against hematogenous seeding of the organism to the meninges. Both the negative Gram stain of the CSF and the failure of the CSF culture to yield organisms until $48 \mathrm{~h}$ of incubation suggest that there was a very low inoculum of organisms in the CSF at the time of presentation. Thus the meningitis was at an early stage.

In meningitis due to group A streptococci, an upper respiratory tract source of organisms is frequent, being either in the nose, throat, middle ear or sinuses. Of 12 cases of group A streptococcal meningitis in adults, six (50\%) had evidence of a source of infection within the upper respiratory tract, either documented by culture $(9,10,12)$ or suggested by preceding symptoms of an upper respiratory tract infection $(6,14)$. Hematogenous spread to the meninges may also occur. Bacteremia with group A streptococci was documented in four of the 12 cases $(33 \%)(6,8,9,12)$. Three of these four also had evidence of an upper respiratory tract focus, and two had a remote focus of infection, one with septic arthritis of a knee (8), and the other with a post-partum genital tract infection (12).

Interruption of the normal coverings of the meningeal compartment or direct instrumentation of the 
compartment were associated with four of 12 (33\%) meningeal infections. One case followed a frontal skull fracture (7), one was associated with a chronic scalp ulcer extending to bone, one followed cranial surgery (11) and another case followed myelography (13). In the latter two instances the history suggests the possibility that organisms were directly inoculated to the CSF during the procedures.

Penicillin is the drug of choice for treating serious infections due to group A streptococci in those without penicillin allergy (1), and the present patient responded well to this drug. All but one of the previous 11 cases had penicillin or ampicillin included in the treatment regimen. One adult case report is notable for the occurrence of meningitis during intravenous therapy with cefotaxime and the subsequent resolution when therapy was switched to penicillin (8).

The outcome of the present patient was favourable; however, he demonstrated one of the potential pyogenic complications, that being permanent damage to hearing. Other reports of group A streptococcal meningitis are notable for the moderately high rates of complications and death. Of the 12 cases discussed, two (17\%)

\section{REFERENCES}

1. Bisno AL. Streptococcus pyogenes. In: Mandell GL, Douglas RG, Bennett JE, eds. Principles and Practice of Infectious Diseases, 3rd edn. New York: Churchill Livingstone, 1990:1519-28.

2. Klein JO. Reemergence of virulent group A streptococcal infections. Pediatr Infect Dis J 1991;10:S3-6.

3. Bisno AL. Group A streptococcal infections and acute rheumatic fever. N Engl J Med 1991;325:783-93.

4. Belani K, Schlievert PM, Kaplan EL, Ferrieri P. Association of exotoxin-producing group A streptococci and severe disease in children. Pediatr Infect Dis J 1991;10:351-4.

5. Murphy DJ. Group A streptococcal meningitis. Pediatrics 1983;71:1-5.

6. Hempling SM, Coutinho M de LP. Streptococcal meningitis. Br Med J 1971;2:166.

7. Jones SR, Luby JP, Sanford JP. Bacterial meningitis complicating cranial-spinal trauma. J Trauma 1973;13:895-900. resulted in death in spite of appropriate antibiotic therapy instituted after brief (one- to two-day) histories of meningeal symptoms $(6,11)$. Two other patients recovered but had complications, one having mild hearing impairment and the other a unilateral optic neuritis. The remaining seven patients (58\%) recovered fully.

\section{CONCLUSIONS}

Group A streptococci are an uncommon but serious cause of meningitis in adults. The infection most frequently begins from a focus in the upper respiratory tract or a contiguous focus associated with mechanical disruption of the normal meningeal compartment. Less often there is a distal focus with bacteremic seeding of the meninges. The progression from apparent health to severe disease is rapid, occurring over a few days. It is clearly important to diagnosis the infection and institute appropriate therapy as rapidly as possible in order to avoid morbidity and mortality, which occur frequently. Intravenous penicillin is the treatment of choice and is generally effective. With the recent reports of increasing serious infections with group A streptococci, cases of meningitis may become more frequent.

8. Ianinni PB, Kunkel MJ. Cefotaxime failure in group A streptococcal meningitis. JAMA 1982;248:1878.

9. Peterson G, Smith P, Loomis G, Osterholm R. Group A streptococcal meningitis in an adult. Nebr Med $\mathrm{J}$ 1985;70:233-5.

10. Kikkawa T, Jkeda S, Takeda S, et al. A case report of a pregnant woman with severe bacterial meningitis caused by group A beta-haemolytic streptococcus. Rinsho Shinkeigaku 1986;26:343-7.

11. Chotmongkol V, Prathipanawatra T, Rojviroj S. Group A beta-haemolytic streptococcal meningitis in adults. J Med Assoc Thai 1989;72:545-7.

12. Quinney RA, Ali MR, Thomas MG, Lang SDR. Post-partum streptococcal meningitis and septicemia. N Z Med J 1984;61:648-51.

13. Damani NN, Chin ATL. Streptococcus pyogenes meningitis after myelography. J Pak Med Assoc 1988;7:885-6.

14. Chow JW, Muder RR. Group A streptococcal meningitis. Clin Infect Dis 1992;14:418-21. 


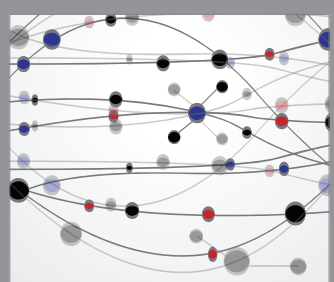

The Scientific World Journal
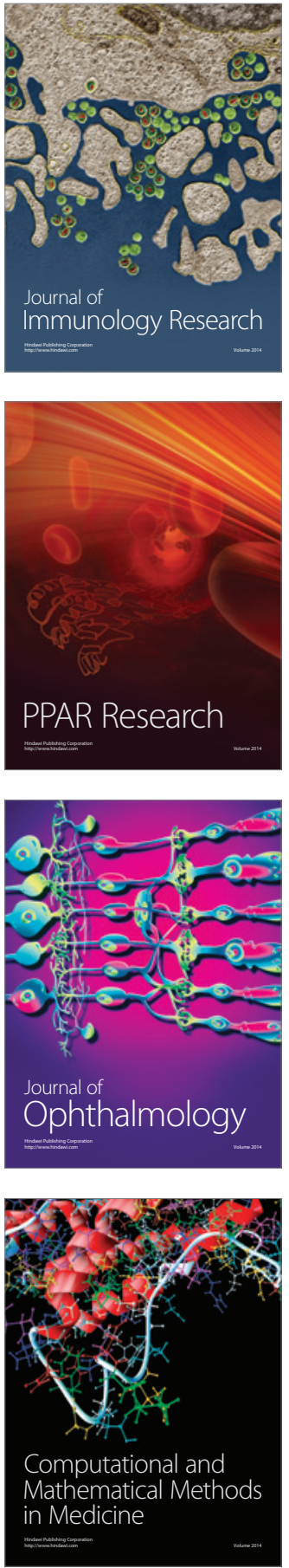

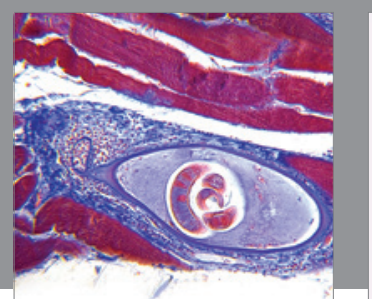

Gastroenterology Research and Practice

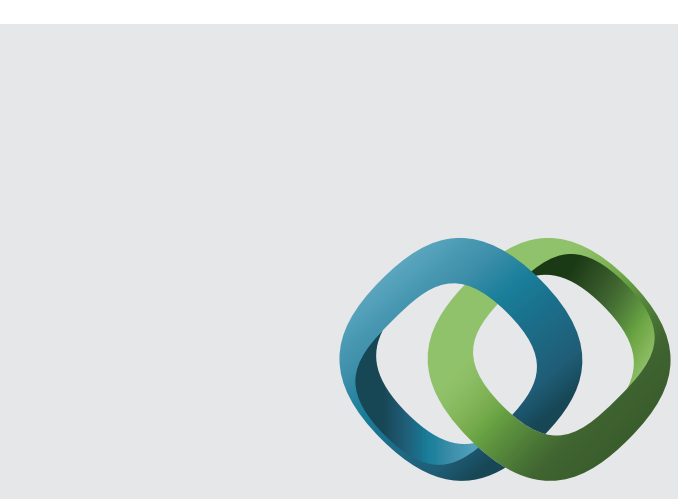

\section{Hindawi}

Submit your manuscripts at

http://www.hindawi.com
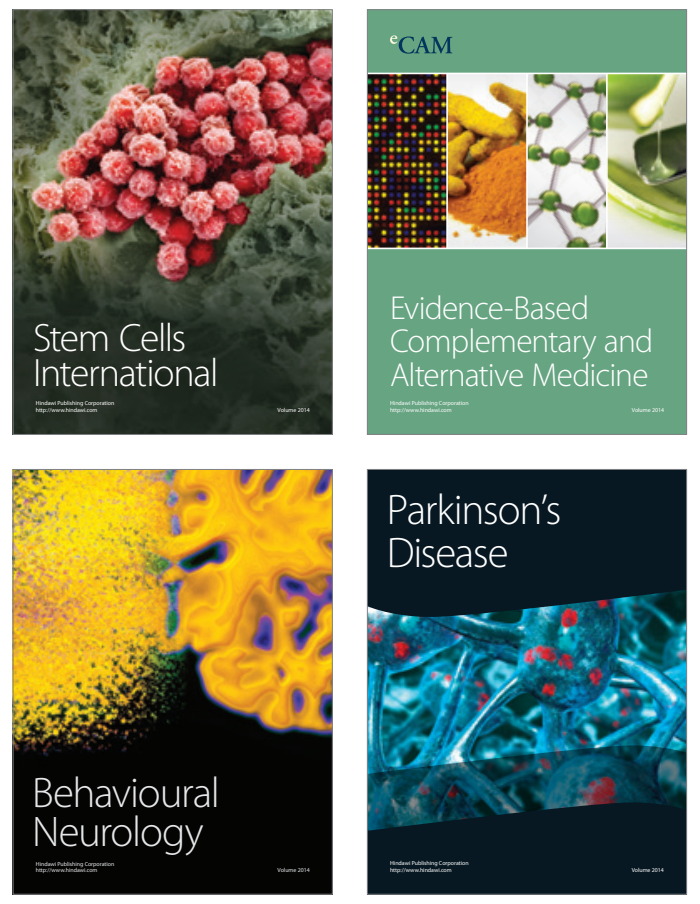
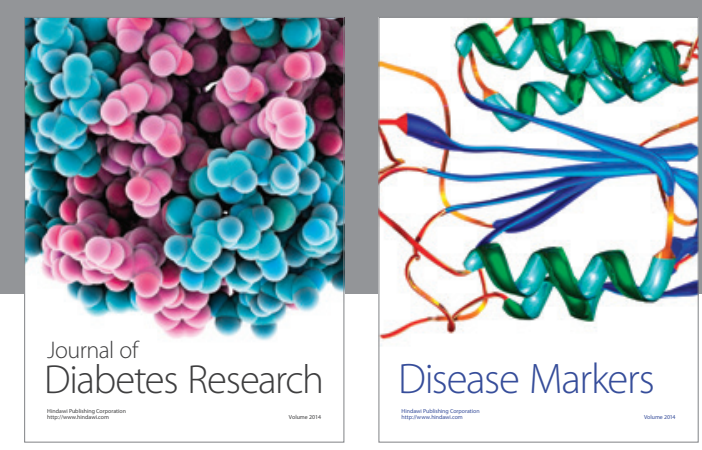

Disease Markers
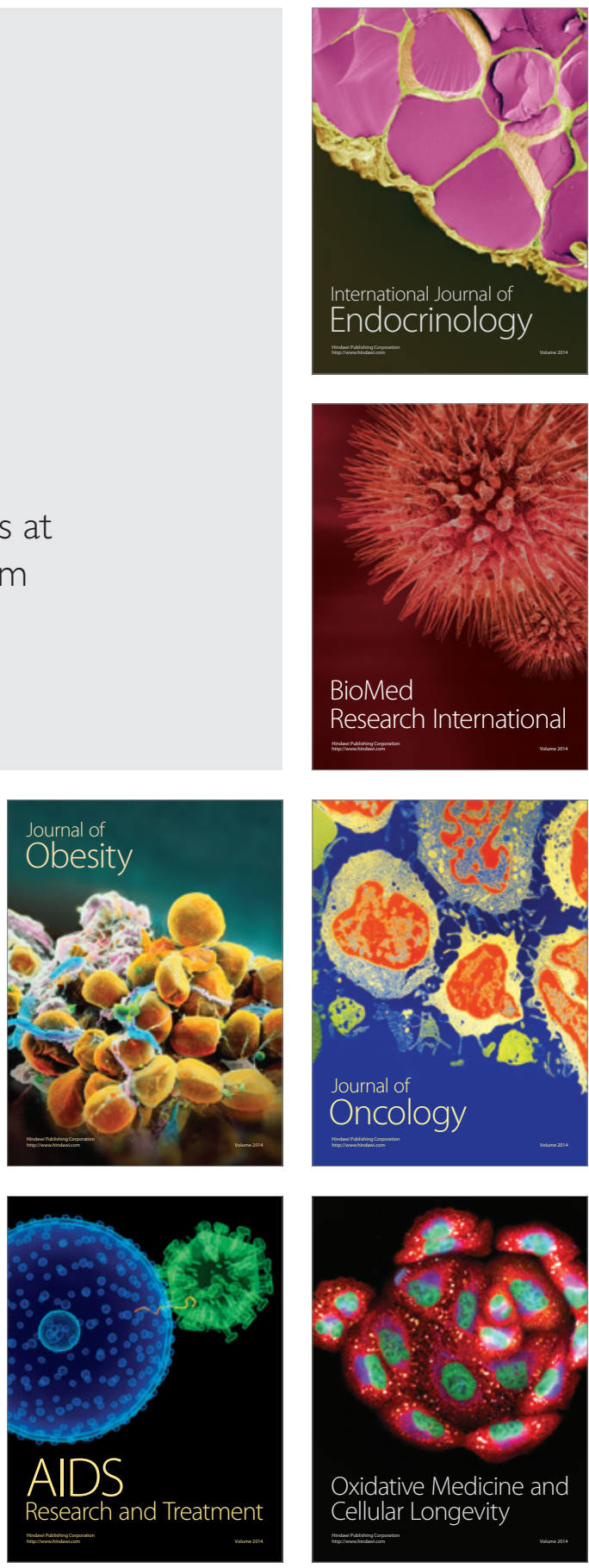